\title{
IMPACT-TOUGHNESS INVESTIGATIONS OF DUPLEX STAINLESS STEELS
}

\author{
PREISKAVE UDARNE ŽILAVOSTI DUPLEKSNEGA NERJAVNEGA \\ JEKLA
}

\author{
Santina Topolska ${ }^{1}$, Jerzy Labanowski ${ }^{2}$ \\ ${ }^{1}$ Silesian University of Technology, Institute of Engineering Materials and Biomaterials, Konarskiego Street 18a, 44-100 Gliwice, Poland \\ ${ }^{2}$ Gdańsk University of Technology, Faculty of Mechanical Engineering, Narutowicza St. 11/12, 80-233 Gdańsk, Poland \\ santina.topolska@polsl.pl \\ Prejem rokopisa - received: 2014-07-30; sprejem za objavo - accepted for publication: 2014-09-15
}

Duplex stainless steels are very attractive constructional materials for use in aggressive environments because of their several advantages over austenitic stainless steels. Duplex steels have excellent pitting and crevice corrosion resistance, are highly resistant to chloride stress-corrosion cracking and are about twice as strong as common austenitic steels. Better properties are associated with their microstructures consisting of ferrite and austenite grains. However, with certain thermal treatments, these excellent properties may be reduced due to undesired changes in the steel microstructure, related mainly to different solid-state-precipitation processes. The impact toughness of the commercial 2205 duplex stainless steel and the higher-alloy super-duplex 2507 steel was investigated. Both steels were submitted to the ageing treatment in a temperature range between $500{ }^{\circ} \mathrm{C}$ and $900{ }^{\circ} \mathrm{C}$ with the exposure times of $6 \mathrm{~min}, 1 \mathrm{~h}$ and $10 \mathrm{~h}$; in addition, light microscope examinations, hardness measurements and impact-toughness tests were performed. The main objective of the investigations was to determine the effect of the change in the microstructure on the mechanical properties of the steel.

Keywords: duplex stainless steels, heat treatment, impact toughness

Dupleksna nerjavna jekla so zanimiv konstrukcijski material za uporabo v agresivnem okolju, ker imajo nekaj prednosti v primerjavi z avstenitnimi nerjavnimi jekli. Dupleksna jekla imajo odlično odpornost proti jamičasti in špranjski koroziji, so odporna proti napetostnim korozijskim pokanjem v kloridnem okolju in so okrog dvakrat bolj trdna kot avstenitna nerjavna jekla. Boljše lastnosti so povezane z njihovo mikrostrukturo iz zrn ferita in perlita. Vendar pa se njihove odlične lastnosti lahko poslabšajo zaradi neželenih sprememb v mikrostrukturi jekla, ki so predvsem v povezavi s procesi izločanja iz trdne raztopine. Preiskovana je bila udarna žilavost komercialnega dupleksnega nerjavnega jekla 2205 in bolj legiranega super dupleksnega jekla 2507. Obe jekli sta bili starani v temperaturnem območju med $500{ }^{\circ} \mathrm{C}$ in $900{ }^{\circ} \mathrm{C}$ v trajanju 6 min, $1 \mathrm{~h}$ in $10 \mathrm{~h}$. Izvršene so bile preiskave s svetlobnim mikroskopom in meritve trdote ter udarne žilavosti. Glavni namen preiskave je bil določiti vpliv sprememb v mikrostrukturi na mehanske lastnosti jekla.

Ključne besede: dupleksna nerjavna jekla, toplotna obdelava, udarna žilavost

\section{INTRODUCTION}

The microstructure of duplex stainless steel consists of austenite and ferrite phases, combining beneficial properties of both kinds of steel, showing a good corrosion resistance, a good weldability and a high strength. The properties of duplex steels depend on their chemical compositions and microstructures. These steels have $22 \%$ to $27 \%$ chromium, $3 \%$ to $7 \%$ nickel and up to $4.5 \%$ molybdenum and are usually used for chemical tankers, desalination plants, chemical and petrochemical units, pipelines and oil and gas separators. ${ }^{1-3}$

Duplex stainless steels are a family of grades with different corrosion-resistance levels depending on their chemistry and they are divided into four groups. ${ }^{4}$ The first group, the lean duplex steels (like 2304) contain no nominal molybdenum addition, but $21.5 \%$ to $24.5 \% \mathrm{Cr}$, $3 \%$ to $5.5 \% \mathrm{Ni}$ and $0.05 \%$ to $0.60 \%$ Mo. The second and the most common group includes the typical 2205 duplex steel with $21 \%$ to $23 \% \mathrm{Cr}, 4.5 \%$ to $6.5 \% \mathrm{Ni}$ and $2.5 \%$ to $3.5 \%$ Mo. The third group includes alloys
255 and DP-3 with $24 \%$ to $27 \% \mathrm{Cr}, 4.5 \%$ to $7.5 \% \mathrm{Ni}$ and $2.9 \%$ to $7.5 \%$ Mo. Higher-alloy super-duplex 2507 grades consist of $24 \%$ to $26 \% \mathrm{Cr}, 6 \%$ to $8 \% \mathrm{Ni}, 3 \%$ to $5 \%$ Mo.

Two most commonly used duplex steels, 2205 and 2507, were chosen for the investigation. The mechanical properties of these duplex grades are excellent in the temperature range from $-50{ }^{\circ} \mathrm{C}$ to $300{ }^{\circ} \mathrm{C}$. At elevated temperatures different precipitates may form and cause detrimental changes in the steel properties, especially the toughness. ${ }^{5}$ During the tempering in the temperature range of $500-900{ }^{\circ} \mathrm{C}$ changes in the microstructure and a precipitation of intermetallic phases can be observed; these reduce the mechanical properties and the corrosion resistance. In certain temperature ranges the first precipitates form rapidly. ${ }^{6,7}$ In Figure 1 an isothermal precipitation diagram for 2205 and 2507 duplex stainless steels (2304 grade is presented for comparison) is depicted. It shows that, in a relatively short time of 1-2 $\mathrm{min}$, the chromium carbide and nitride precipitation process starts. The kinetics of the carbide and nitride formation is 


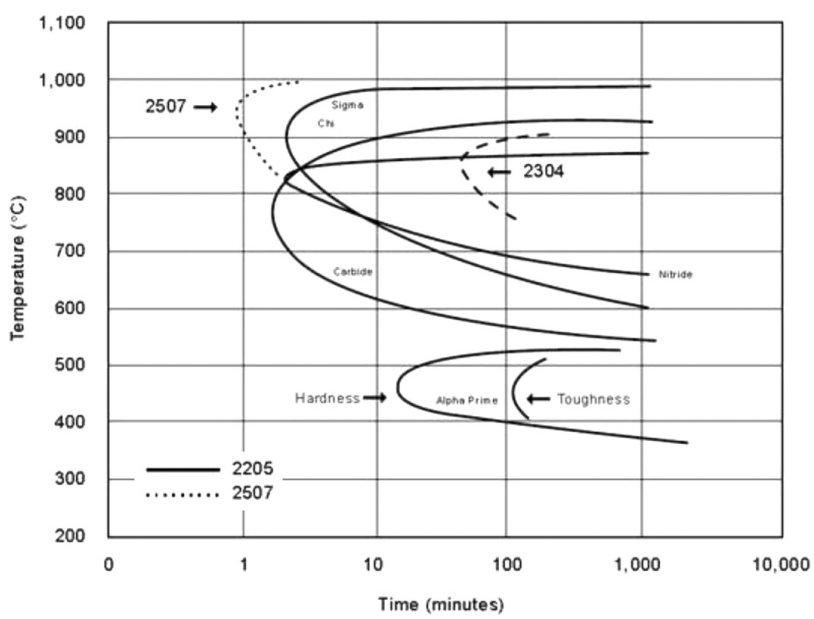

Figure 1: Isothermal precipitation diagram for duplex stainless steels, annealed at $1050{ }^{\circ} \mathrm{C}^{4}$

Slika 1: Izotermni diagram izločanja v dupleksnem nerjavnem jeklu, žarjenem na $1050^{\circ} \mathrm{C}{ }^{4}$

affected by chromium, molybdenum and nickel. This is why the kinetics of all the nitrogen-alloyed duplex stainless-steel grades is similar to that of steel 2205 with regard to these precipitates. A sigma and chi precipitation occurs at higher temperatures. Super-duplex grades that are highly alloyed with chromium, molybdenum and nickel will have more rapid sigma and chi kinetics than steel 2205.

Table 1: Secondary phases forming in duplex stainless steels (temperatures above $\left.500{ }^{\circ} \mathrm{C}\right)^{8}$

Tabela 1: Sekundarne faze, ki nastajajo v dupleksnem nerjavnem jeklu (temperature nad $\left.500{ }^{\circ} \mathrm{C}\right)^{8}$

\begin{tabular}{|c|c|c|}
\hline Type of precipitate & $\begin{array}{c}\text { Nominal chemical } \\
\text { formula }\end{array}$ & $\begin{array}{c}\text { Temperature range } \\
\left({ }^{\circ} \mathrm{C}\right)\end{array}$ \\
\hline Ferrite $(\alpha)$ & - & - \\
Austenite $(\gamma)$ & - & - \\
$\sigma$ & $\mathrm{Fe}-\mathrm{Cr}-\mathrm{Mo}$ & $600-1000$ \\
Chromium nitride & $\mathrm{Cr}-\mathrm{N}$ & $700-900$ \\
Chromium nitride & $\mathrm{CrN}$ & 1000 \\
$\chi$ & $\mathrm{Fe}_{36} \mathrm{Cr}_{12} \mathrm{Mo}_{10}$ & $700-900$ \\
$\mathrm{R}$ & $\mathrm{Fe}^{-\mathrm{Cr}_{-}-\mathrm{Mo}_{0}}$ & $550-800$ \\
$\pi$ & $\mathrm{Fe}_{7} \mathrm{Mo}_{13} \mathrm{~N}_{4}$ & $550-600$ \\
$\tau$ & - & $550-650$ \\
$\mathrm{M}_{7} \mathrm{C}_{3}$ & - & $550-650$ \\
$\mathrm{M}_{23} \mathrm{C}_{6}$ & - & \\
\hline
\end{tabular}

The most important secondary phases during the manufacturing and welding of duplex steels are $\sigma, \chi$, secondary austenite and chromium nitrides. All these phases are formed above $500{ }^{\circ} \mathrm{C}$. The sigma and chi precipitation occurs at slightly higher temperatures but in approximately equal precipitation time as the carbide and nitride precipitation. Table 1 lists the secondary phases found in duplex stainless steels and weld metals above $500{ }^{\circ} \mathrm{C} .{ }^{8}$ Below $500{ }^{\circ} \mathrm{C}$ the precipitation reactions are comparatively slow, having little effect on the embrittlement. The $475{ }^{\circ} \mathrm{C}$ embrittlement is due to the decomposition of ferrite between $350{ }^{\circ} \mathrm{C}$ and $525^{\circ} \mathrm{C}$, into the $\alpha^{\prime}$ phase which precipitates in the ferrite phase and causes a hardening and embrittlement of the ferrite. ${ }^{4}$

Numerous research studies describe the precipitation phenomena in $\mathrm{Cr}-\mathrm{Ni}$ stainless steels; $;{ }^{6},-13$ however, there is yet no clear evidence on the amount of acceptable secondary phases in a steel microstructure. The objective of the investigations was to study the effect of heat treatment of duplex and super-duplex steels on their mechanical properties, impact toughness and strength, and to analyze the changes in the steel microstructure.

\section{EXPERIMENTAL PROCEDURE}

Commercial grades 2205 and 2507, with their chemical compositions shown in Table 2, were investigated. The specimens were cut from plates $12 \mathrm{~mm}$, preannealed at $1050{ }^{\circ} \mathrm{C}$ and isothermally tempered in a vacuum furnace for $6 \mathrm{~min}, 1 \mathrm{~h}$ and $10 \mathrm{~h}$ at temperatures from $500{ }^{\circ} \mathrm{C}$ to $900{ }^{\circ} \mathrm{C}$ and water quenched. The microstructure was examined after chemical etching in Murakami and Beraha's reagents. The amount of the phases was assessed with a magnetic ferritoscopic analysis and a quantitative microstructure analysis.

Table 2: Chemical compositions of tested 2205 and 2507 duplex stainless steels

Tabela 2: Kemijska sestava preizkušanih dupleksnih nerjavnih jekel 2205 in 2507

\begin{tabular}{|cc|c|c|c|c|c|c|}
\hline \multirow{2}{*}{ Duplex grade } & \multicolumn{6}{|c|}{$w / \%$} \\
\cline { 2 - 8 } & $\mathrm{C}$ & $\mathrm{Mn}$ & $\mathrm{Cr}$ & $\mathrm{Ni}$ & $\mathrm{Mo}$ & $\mathrm{N}$ \\
\hline 2205 & $\mathrm{~S} 31803$ & 0.017 & 1.50 & 21.9 & 5.7 & 3.0 & 0.17 \\
\hline 2507 & $\mathrm{~S} 32550$ & 0.030 & 0.87 & 25.12 & 5.82 & 3.59 & 0.29 \\
\hline
\end{tabular}

The initial Vickers hardness of the base materials was 254 HV 10 for the 2205 steel grade and 270 HV 10 for the 2507 steel grade. Charpy V impact tests were performed at ambient temperature $\left(+20^{\circ} \mathrm{C}\right)$ on the specimens with a notch that was orthogonal to the plate's longitudinal direction. The as-delivered specimens had high fracture energy $(\approx 300 \mathrm{~J})$.

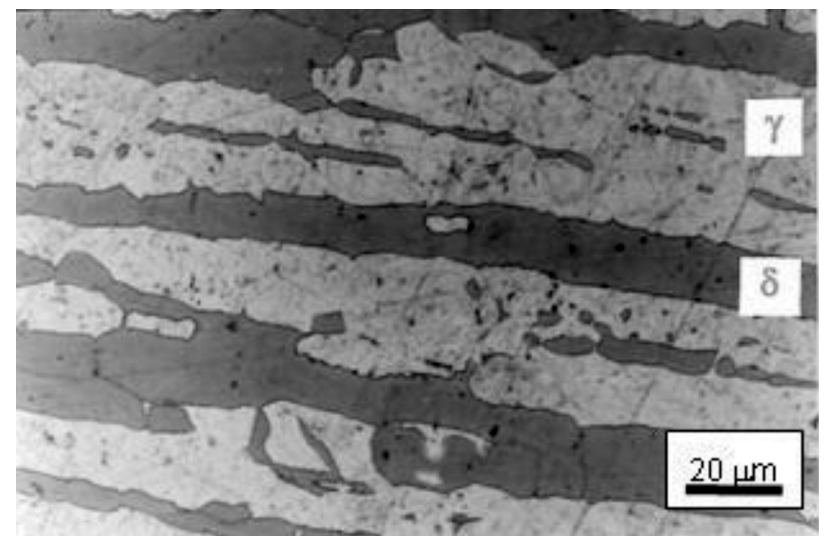

Figure 2: Microstructure of the as-delivered 2205 duplex stainless steel

Slika 2: Mikrostruktura dupleksnega nerjavnega jekla 2205 v dobavljenem stanju 


\section{RESULTS AND DISCUSSION}

Due to the used treatments different phases (intermetallic phases, $\mathrm{Cr}_{2} \mathrm{~N}$ and secondary austenite) were formed, with the $\sigma$-phase as the most important one beside ferrite and austenite and with the largest volume fraction. Figure 2 presents the microstructure of the as-received 2205 duplex steel with an elongated lamellar shape of the rolled ferrite and austenite (the light etched phase is austenite and the dark etched one is ferrite). In the as-received state, the microstructure of grade 2507 is similar to that of grade 2205 . The ferrite content in the microstructure of steel 2205 was $44-47 \%$ and in steel 2507 it was $52-55 \%$. The specimens of both steels being aged at $500{ }^{\circ} \mathrm{C}$, even in the case of the longest aging time, do not exhibit any significant phase transformation; only the amount of ferrite is slightly decreased due to the nucleation of secondary austenite $\gamma_{2}$.

In duplex steels, the ferrite is unstable at elevated temperatures $\left(600{ }^{\circ} \mathrm{C}\right.$ and $\left.900{ }^{\circ} \mathrm{C}\right)$ because of the high diffusion rates of dissolved alloying elements, which were 100 times faster than in the case of austenite. Moreover, the ferrite is enriched in chromium and molybdenum, thus promoting the formation of intermetallic phases.
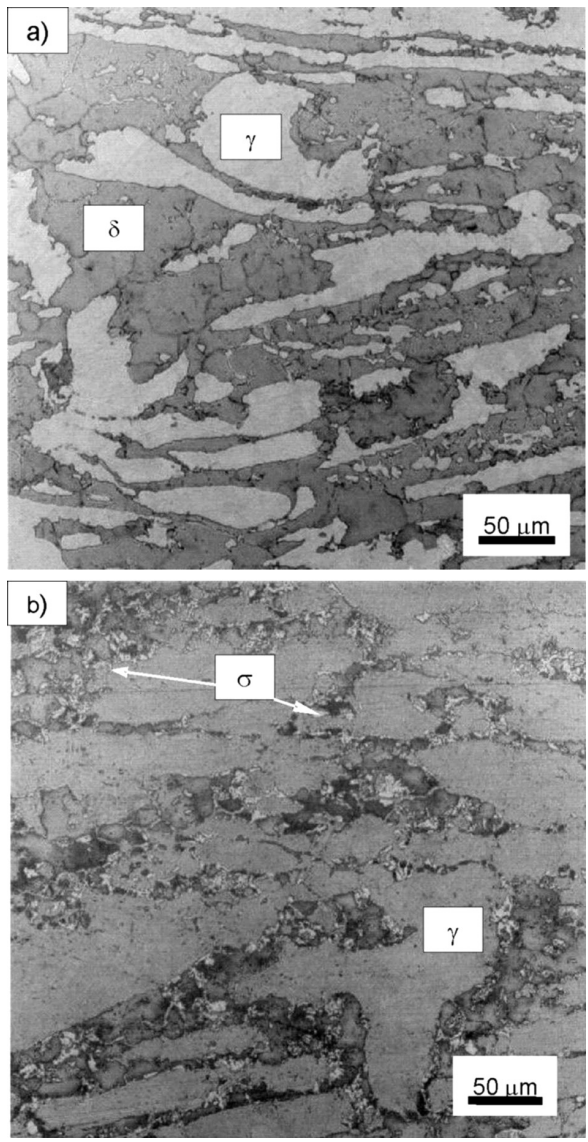

Figure 3: Formation of $\sigma$-phase (eutectoid reaction) in 2205 duplexsteel grade aged at $800{ }^{\circ} \mathrm{C}$ for: a) $6 \mathrm{~min}$, b) $1 \mathrm{~h}$

Slika 3: Tvorba $\sigma$-faze (evtektoidna reakcija) v dupleksnem nerjavnem jeklu 2205, staranem na $800{ }^{\circ} \mathrm{C}$ : a) $6 \mathrm{~min}$, b) $1 \mathrm{~h}$
On the other hand, the formation of secondary austenite is independent of the $\sigma$-phase precipitation although these two transformations occur simultaneously and are both related to the ferrite phase. The mechanism of the $\sigma$-phase formation depends on the temperature; below $900{ }^{\circ} \mathrm{C}$ and after a longer ageing period, the $\sigma$-phase is formed by the eutectoid reaction $\delta \rightarrow \sigma+\gamma_{2}$. First, the $\sigma$-phase forms inside the ferrite grains, then it starts to form at the ferrite/ferrite or ferrite/austenite grain boundaries. At $900{ }^{\circ} \mathrm{C}$ and above this temperature ferrite transforms into the $\sigma$-phase without an austenite formation and the composition of the $\sigma$-phase is close to ferrite.

Comparing the two considered duplex steel grades, it is evident that grade 2205 is less prone to the $\sigma$-phase precipitation than grade 2507. In grade 2205, the precipitation of the $\sigma$-phase is observed after $10 \mathrm{~h}$ of ageing at the temperatures of $600{ }^{\circ} \mathrm{C}$ and $700{ }^{\circ} \mathrm{C}$. The specimens of grade 2205 aged at $800{ }^{\circ} \mathrm{C}$ show the $\sigma$-phase precipitation after less than $1 \mathrm{~h}$ (Figure 3) and due to the ageing at $900{ }^{\circ} \mathrm{C}$ the $\sigma$-phase formation occurs in less than $6 \mathrm{~min}$. In the case of super-duplex steel 2507 , the precipitation of small aggregations of the $\sigma$-phase was observed already after $6 \mathrm{~min}$ of ageing at $700{ }^{\circ} \mathrm{C}$. The specimens aged at $800{ }^{\circ} \mathrm{C}$ and $900{ }^{\circ} \mathrm{C}$ (Figure 4)

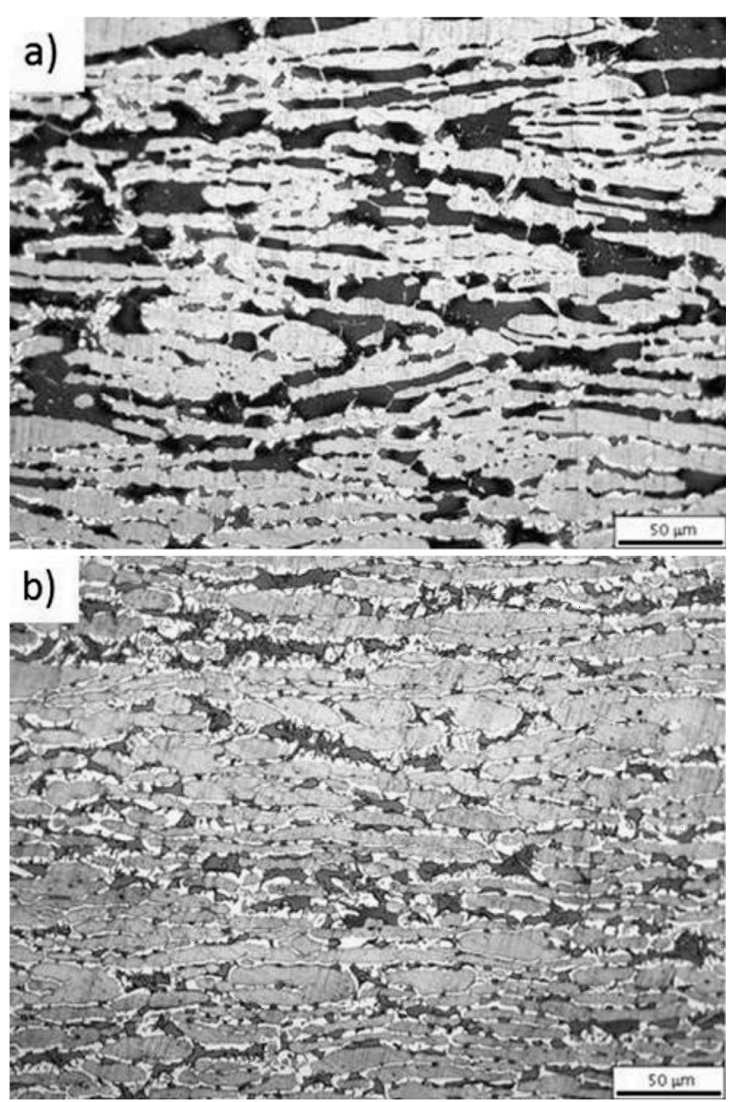

Figure 4: Formation of $\sigma$-phase (directly from ferrite) in 2507 duplex steel grade aged at $900{ }^{\circ} \mathrm{C}$ for: a) $6 \mathrm{~min}$, b) $1 \mathrm{~h}$

Slika 4: Tvorba $\sigma$-faze (neposredno iz ferita) v dupleksnem nerjavnem jeklu 2507, staranem na $900{ }^{\circ} \mathrm{C}$ : a) $6 \mathrm{~min}$, b) $1 \mathrm{~h}$ 


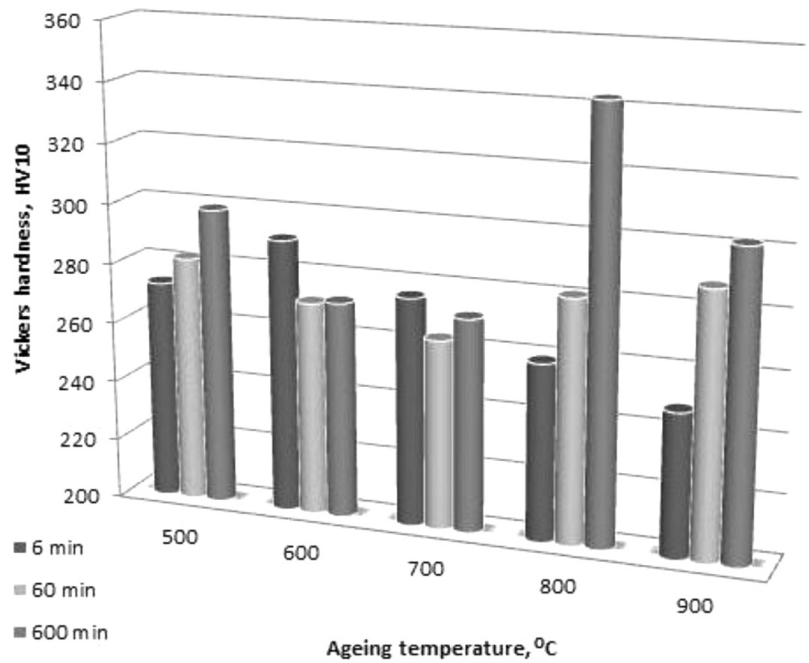

Figure 5: Influence of the ageing time and temperature on the hardness of 2205 duplex stainless steel

Slika 5: Vpliv časa in temperature staranja na trdoto dupleksnega nerjavnega jekla 2205

show, already after $6 \mathrm{~min}$, advanced ferrite-phase disintegration. In the cases of lower ageing temperatures (500 ${ }^{\circ} \mathrm{C}, 600{ }^{\circ} \mathrm{C}$ ) and shorter aging times (6 min, $60 \mathrm{~min}$ ) no $\sigma$-phase was observed in the microstructures.

The next detailed investigations were conducted to determine the correlation between certain mechanical properties (hardness and embrittlement) and the microstructure. The $\alpha^{\prime}$-phase precipitations caused a slight hardness increase in both investigated duplex steels being aged at $500{ }^{\circ} \mathrm{C}$. In steel grade 2205 the ageing at $600{ }^{\circ} \mathrm{C}$ and $700{ }^{\circ} \mathrm{C}$ caused a small decrease in the steel hardness (Figure 5), probably due to the creation of the $\gamma_{2}$-phase. Further ageing at higher temperatures causes a precipitation of the $\sigma$-phase and a significant hardness increase. The maximum hardness values were 348 HV10

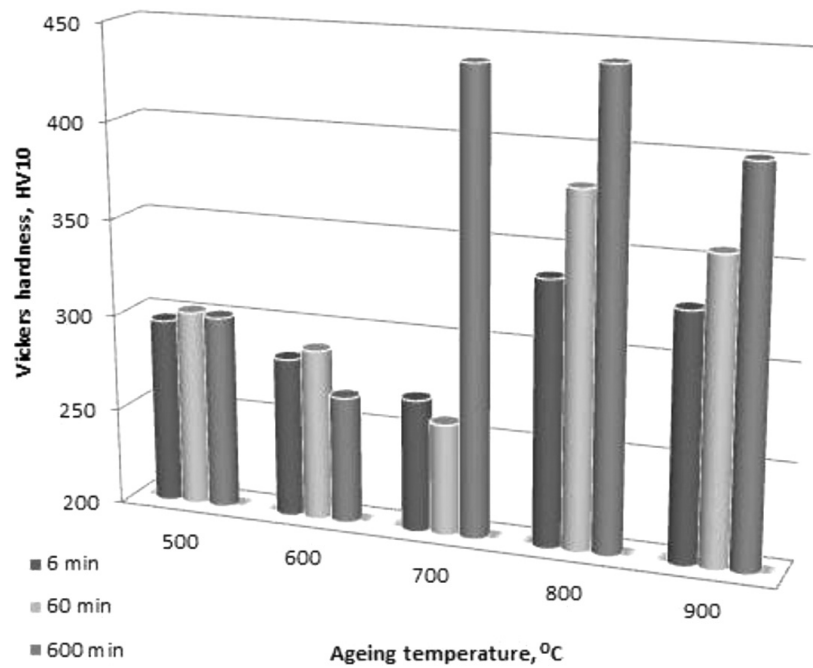

Figure 6: Influence of the ageing time and temperature on the hardness of 2507 super-duplex stainless steel

Slika 6: Vpliv časa in temperature staranja na trdoto super dupleksnega nerjavnega jekla 2507

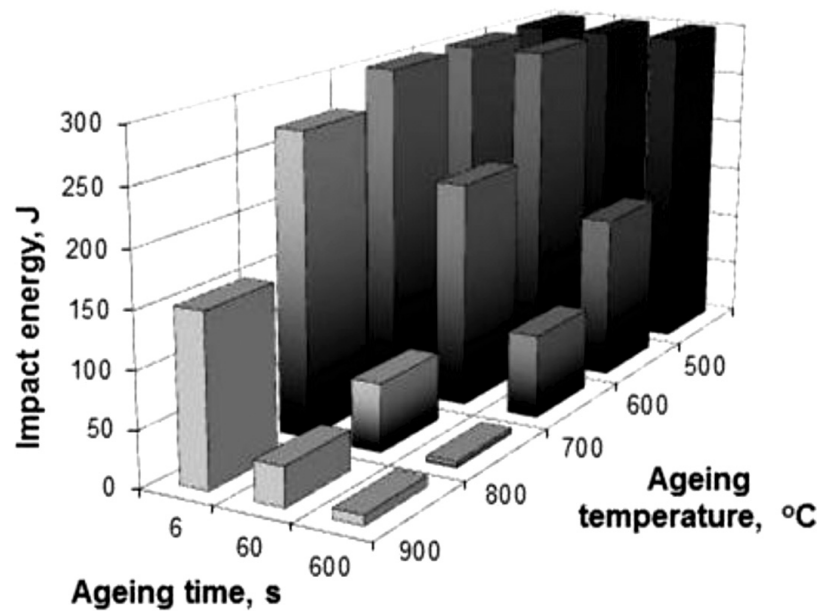

Figure 7: Influence of the ageing time and temperature on the impact energy of 2205 duplex stainless steel

Slika 7: Vpliv časa in temperature staranja na energijo udarca dupleksnega nerjavnega jekla 2205

for steel 2205 after $10 \mathrm{~h}$ of ageing at $800{ }^{\circ} \mathrm{C}$ and 94 HV10 for duplex steel grade 2507 . The ageing at $600{ }^{\circ} \mathrm{C}$ caused a small decrease in the steel hardness, while the ageing at $700{ }^{\circ} \mathrm{C}$ significantly increased the hardness (Figure 6). The super-duplex 2507 steel showed the highest hardness of 438-441 HV10 after $10 \mathrm{~h}$ of ageing at $700{ }^{\circ} \mathrm{C}$ and $800{ }^{\circ} \mathrm{C}$ and the hardness increase for steel grade 2507 was $171 \mathrm{HV} 10$. The ageing of both analyzed steel grades at $900{ }^{\circ} \mathrm{C}$ increased the hardness less than the ageing at $800{ }^{\circ} \mathrm{C}$, probably due to a smaller amount of precipitates. Unlike the hardness, the embrittlement behavior of the analyzed specimens of duplex steel grades was different and the 2205 duplex was less sensitive to embrittlement (Figure 7). A short time $(6 \mathrm{~min})$ of ageing at the temperatures up to $800{ }^{\circ} \mathrm{C}$ did not remarkably decrease the impact energy. At $900{ }^{\circ} \mathrm{C}$ the impact energy fell to a value of $150 \mathrm{~J}$. The ageing for $1 \mathrm{~h}$ caused

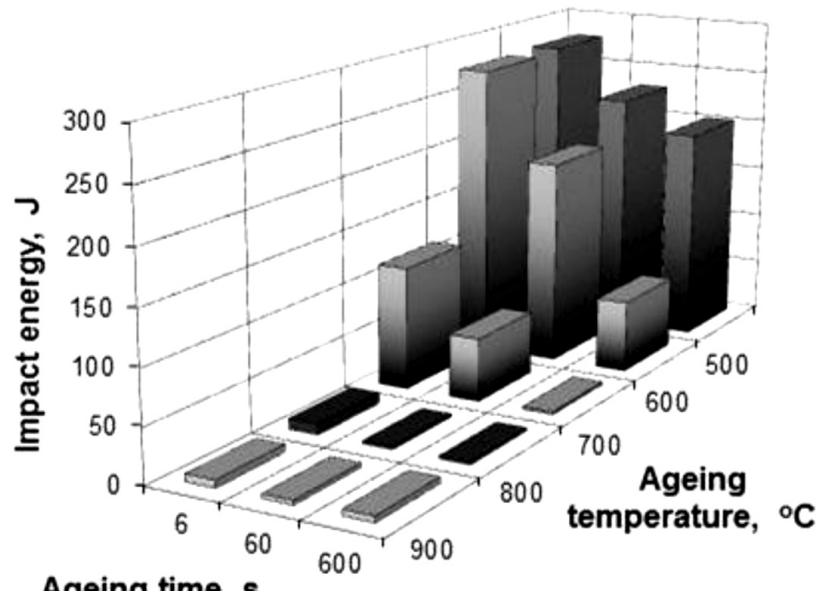

Ageing time, s

Figure 8: Influence of the ageing time and temperature on the impact energy of 2507 super-duplex stainless steel

Slika 8: Vpliv časa in temperature staranja na energijo udarca super dupleksnega nerjavnega jekla 2507 


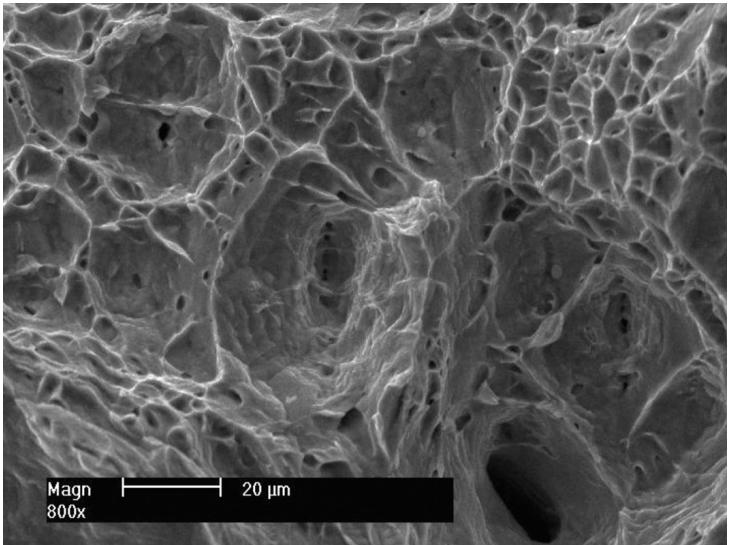

Figure 9: Fracture surface of the specimen aged at $500{ }^{\circ} \mathrm{C}$ for $1 \mathrm{~h}$ Slika 9: Površina preloma vzorca, staranega $1 \mathrm{~h}$ na $500{ }^{\circ} \mathrm{C}$

a decrease in the impact energy starting at $700{ }^{\circ} \mathrm{C}$ and the greatest change occurred at $800{ }^{\circ} \mathrm{C}$. During the ageing for $10 \mathrm{~h}$ at $500{ }^{\circ} \mathrm{C}$ the high toughness remained at the level of $300 \mathrm{~J}$, while at higher temperatures a significant decrease in the impact energy was observed. The 2507 super-duplex steel showed a high toughness after the ageing for $6 \mathrm{~min}$ at $500{ }^{\circ} \mathrm{C}$ and $600{ }^{\circ} \mathrm{C}$ (Figure 8) and at $700{ }^{\circ} \mathrm{C}$ the impact energy decreased by more than half. With the average ageing time $(1 \mathrm{~h})$, the impact energy decreased from about $250 \mathrm{~J}$ at $500{ }^{\circ} \mathrm{C}$ to almost zero at $800{ }^{\circ} \mathrm{C}$ and $900{ }^{\circ} \mathrm{C}$. Finally, after $10 \mathrm{~h}$ of ageing the impact energy was on a decrease from $200 \mathrm{~J}$ at $500{ }^{\circ} \mathrm{C}$ to $100 \mathrm{~J}$ at $600{ }^{\circ} \mathrm{C}$, approaching zero at the temperatures above $600{ }^{\circ} \mathrm{C}$. It should be stated that higher temperatures remarkably reduce the steel plasticity and may cause an almost complete decrease in the toughness.

The change in the mechanical properties was investigated with scanning electron microscopy with the main aim to determine the correlation between the impact toughness and fracture mode by examining the fractures of Charpy V specimens. The macroscopic observation of fracture surfaces showed many secondary cracks or splits. The literature information ${ }^{14}$, according to which

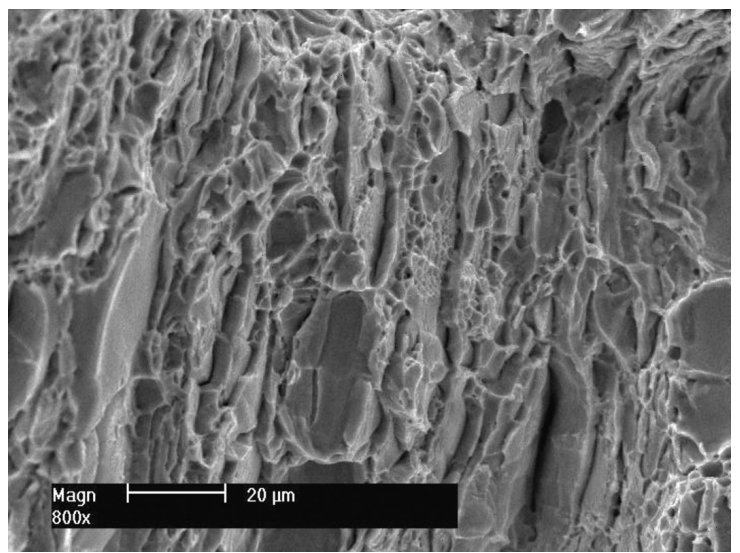

Figure 10: Fracture surface of the specimen aged at $700{ }^{\circ} \mathrm{C}$ for $1 \mathrm{~h}$ Slika 10: Površina preloma vzorca, staranega $1 \mathrm{~h}$ na $700{ }^{\circ} \mathrm{C}$

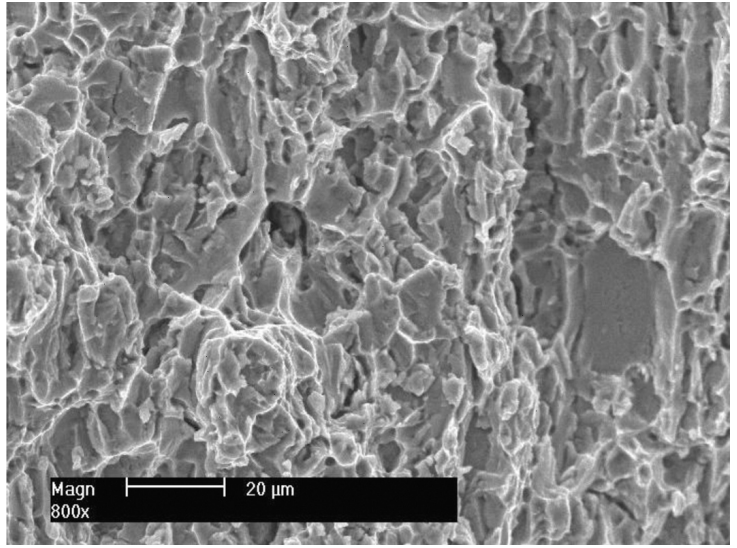

Figure 11: Fracture surface of the specimen aged at $900{ }^{\circ} \mathrm{C}$ for $1 \mathrm{~h}$ Slika 11: Površina preloma vzorca, staranega $1 \mathrm{~h}$ na $900{ }^{\circ} \mathrm{C}$

the splits propagate through the ferrite phase or ferriteaustenite boundaries, was confirmed. The fractures of the samples tempered at $600{ }^{\circ} \mathrm{C}$ and $700{ }^{\circ} \mathrm{C}$ for up to $1 \mathrm{~h}$ were ductile and had dimpled fracture surfaces, with the dimples being elongated in the stress direction (Figure 9). With higher ageing temperatures and longer annealing times the fractures were mixed. The sample annealed at $700{ }^{\circ} \mathrm{C}$ showed a cleavage fracture and small areas with dimples (Figure 10). Brittle fracture was found on the samples treated at $800{ }^{\circ} \mathrm{C}$ and $900{ }^{\circ} \mathrm{C}$ (Figure 11).

\section{CONCLUSIONS}

The research was focused on the potential and future applications of duplex steels, ${ }^{15}$ as for many of them the mechanical properties are of an essential importance. The results indicate a negative effect of the changes to the mistrostructures of duplex steels on their mechanical

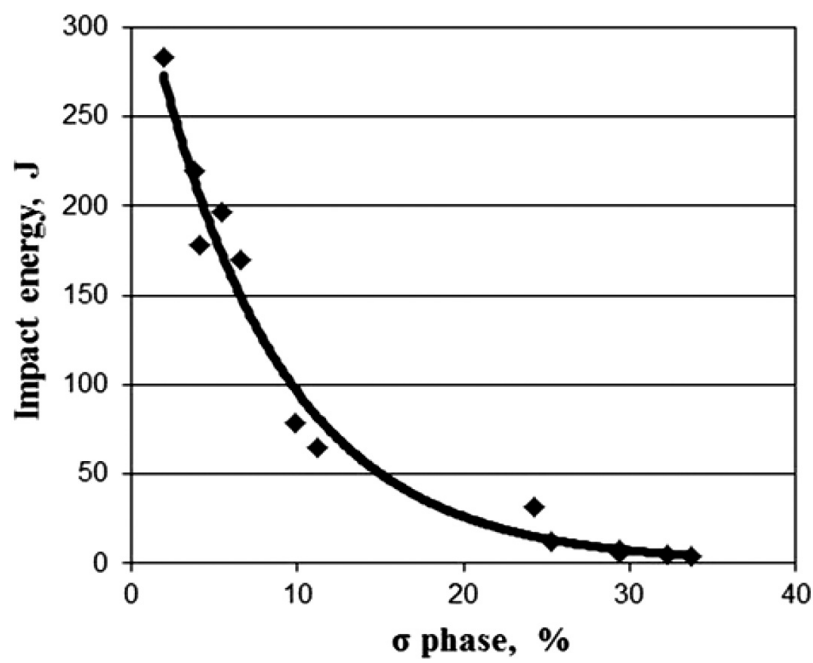

Figure 12: Influence of the $\sigma$-phase content on the impact energy of 2205 duplex stainless steel

Slika 12: Vpliv vsebnosti $\sigma$-faze na energijo udarca pri dupleksnem nerjavnem jeklu 2205 


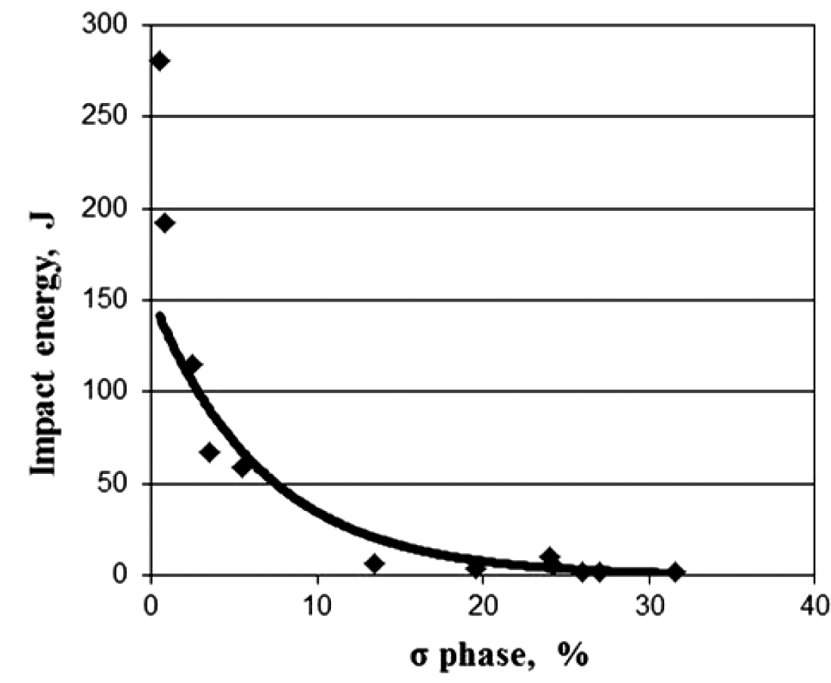

Figure 13: Influence of the $\sigma$-phase content on the impact energy of 2507 super-duplex stainless steel

Slika 13: Vpliv vsebnosti $\sigma$-faze na energijo udarca pri super dupleksnem nerjavnem jeklu 2507

properties. Precipitates, mainly the $\sigma$-phase, decrease the plasticity of duplex 2205 and super-duplex 2507 stainless steels as, due to small amounts of the $\sigma$-phase in the steel microstructures, the toughness of both steels decrease considerably. This is a result of the brittleness of the closed-packed $\sigma$-phase lattice. Figures $\mathbf{1 2}$ and $\mathbf{1 3}$ show diagrams of the influence of the $\sigma$-phase amounts in the microstructures of the 2205 and 2507 duplex steels on the impact energy. To determine the amounts of this phase a multi-scan image-analysis system and metallographic specimens were used.

The obtained results can be analyzed with respect to the requirements of Ship Classification Societies. According to the common material-design criterion for wrought products, the impact energy obtained on the Charpy V specimens should be higher than $27 \mathrm{~J}$ or $40 \mathrm{~J}$, depending on the testing temperature and the transverse or longitudinal direction of the specimens. It is obvious that the examined 2205 steel could be used at room temperature provided its $\sigma$-phase content accounts for up to $14 \%(K V>40 \mathrm{~J})$ and the super-duplex 2507 steel could be used with the $\sigma$-phase accounting for up to $8 \%$ of the microstructure (Figures $\mathbf{1 2}$ and 13). The usually accepted amount of the $\sigma$-phase is about $4 \%{ }^{2}$ but some researches ${ }^{16}$ claim that even smaller amounts of the $\sigma$-phase lead to a significant decrease in the toughness and a rapid decrease to the value unacceptable for industrial applications. This statement is compatible with the results presented in our work. Even a very small amount of the $\sigma$-phase in a microstructure caused a measurable decrease in the toughness of the two analyzed steels. The 2507 super-duplex steel is more prone to embrittlement, which is an important criterion for the design and exploitation of steels for the maritime and energy-related technical applications. An undesired and unpredictable temperature growth over $500{ }^{\circ} \mathrm{C}$, lasting for a longer time could cause errors during the processing of duplex stainless steels and accidents during the use of the products.

The results of these investigations confirm that hightemperature service of duplex stainless steels should be avoided. The precipitation of secondary phases strongly influences the mechanical properties, and for the use of steel grade 2205, only limited amounts of the $\sigma$-phase are acceptable.

\section{REFERENCES}

${ }^{1}$ J. Charles, Welding in the World, 36 (1995), 89-97

${ }^{2}$ J. Łabanowski, Apparatus and Chemical Engineering, 36 (1997) 2, 3-10 (in Polish)

${ }^{3}$ A. Gwiazda, Applied Mechanics and Materials, 474 (2014), 417-422, doi:10.4028/www.scientific.net/AMM.474.417

${ }^{4}$ Practical guidelines for the fabrication duplex stainless steels, International Molybdenum Association, London 2001, 48

${ }^{5}$ J. Frodigh, J. Nicholls, Mechanical properties of Sandvik duplex stainless steels, AB Sandvik Steel, Sandviken 1994, 81

${ }^{6}$ X. G. Wang, D. Dumortier, Y. Riquier, Structural evolution of zeron 100 duplex stainless steel between 550 and $1100{ }^{\circ} \mathrm{C}$, Proc. of Conf. Duplex stainless steels '91, Beaune, France, 1991, 127-134

${ }^{7}$ L. Karlsson, L. Ryen, S. Pak, Welding Journal, 1 (1995), 115-122

${ }^{8}$ L. Karlsson, Welding in the world, 43 (1999) 5, 20-40

${ }^{9}$ T. Otarola, S. Hollner, B. Bonnefois, M. Anglada, L. Coudreuse, A. Mateo, Engineering Failure Analysis, 12 (2005), 930-941, doi:10.1016/j.engfailanal.2004.12.022

${ }^{10}$ T. H. Chen, K. L. Weng, J. R. Yang, Materials Science Engineering, A338 (2002), 259-270, doi:10.1016/S0921-5093(02)00093-X

${ }^{11}$ J. Nowacki, P. Rybicki, Journal of Achievements in Materials and Manufacturing Engineering, 17 (2006) 1-2, 113-116

${ }^{12} \mathrm{~J}$. Łabanowski, Journal of Achievements in Materials and Manufacturing Engineering, 20 (2007) 1-2, 255-258

${ }^{13}$ J. Nowacki, A. Łukojć, Journal of Materials Processing Technology, 164-165 (2005), 1074-1081, doi:10.1016/j.jmatprotec.2005.02.243

${ }^{14}$ H. Sieurin, R. Sandström, Engineering Fracture Mechanics, 73 (2006) 4, 377-390, doi:10.1016/j.engfracmech.2005.03.009

${ }^{15}$ A. Gwiazda, Advanced Materials Research, 837 (2014), 393-398, doi:10.4028/www.scientific.net/AMR.837.393

${ }^{16}$ J. Charles, The duplex stainless steels: materials to meet your needs, Proc. of Conf. Duplex stainless steels '91, Beaune, France, 1991, $3-48$ 